\title{
Culture dependent analysis of bacterial diversity in Canada's Raspberry Rising Cave revealed antimicrobial properties
}

\author{
Soumya Ghosh (D) ${ }^{1 ¥}$, Gabrielle Kam (D) ${ }^{1}$, Monique Nijjer (DD ${ }^{2}$, Christian Stenner (D) ${ }^{3}$, \\ and Naowarat Cheeptham (1) ${ }^{1^{*}}$ \\ ${ }^{1}$ Department of Biological Sciences, Thompson Rivers University, 805 TRU Way, Kamloops, BC, Canada \\ ${ }^{\ddagger}$ Present address: Department of Genetics, Natural and Agricultural Sciences, University of the Free State, 205 Nelson Mandela Dr, \\ Park West, Bloemfontein, 9301, South Africa \\ ${ }^{2}$ Department of Biology, The University of British Columbia (Okanagan Campus), 3333 University Way, Kelowna, BC, Canada \\ ${ }^{3}$ Alberta Speleological Society, Calgary, AB, Canada
}

\begin{abstract}
Bacteria and archaea thrive in terrestrial subsurface environments because of their unique physiology. Over time, these unique microorganisms may have adapted to possess specialized metabolic pathways that sustain their continued existence in caves, one of harshest environments on earth. The present study elucidates cultivation based microbial diversity of the cave sediments and wall scrapings collected from seven different locations in Raspberry Rising Cave located in the Columbia Mountain Range, British Columbia, Canada. A total of 103 cultivable bacteria from the cave were isolated on various agar media including R2A, Hickey-Tresner, and Difco ${ }^{\mathrm{TM}}$ Actinomycetes Isolation agar media. Taxonomical phylogenetic analysis of the $16 \mathrm{~S}$ rRNA gene of the bacterial isolates identified three major phyla: Proteobacteria (Class: Gammaproteobacteria) (51.45\%), Actinobacteria $(43.68 \%)$ and Bacteroidetes (3.88\%). Among them, the major genus was Pseudomonas (48.54\%) followed by Rhodococcus (39.80\%) and Flavobacterium (3.88\%). The genus Janthinobacterium and Arthrobacter contributed about $2.91 \%$ each, of the total population. Noteworthy, $0.99 \%$ were recognized as endophytic Proteobacteria. Furthermore, these bacterial isolates were evaluated for their potential antimicrobial activities against the multidrug resistant bacterial strains. Two bacterial isolates (RRC23, RRC75) showed antimicrobial activities against multidrug resistant (MDR) Escherichia coli \#15-318 while RRC48 exhibited against methicillin resistant (MRSA) Staphylococcus aureus. The isolates RRC36 and RRC38 were identified to show antimicrobial activities against non-pathogenic isolates of Staphylococcus aureus. To the best of our knowledge, this is the first scientific study conducted and provides the insight in occurrence and distribution of the cultivated bacterial diversity from the Raspberry Rising Cave. Moreover, the antimicrobial properties exhibited by some of the bacterial isolates suggested that this cave system could be a resource for potential antibiotics, drugs or novel biologics of clinical relevance.
\end{abstract}

Keywords: cave microbial diversity, multi-drug resistant organisms, cultivation-based, antimicrobial activities, Raspberry Rising Cave, marble cave

Received 24 October 2019; Revised 3 March 2020; Accepted 3 March 2020

Citation: Ghosh S., Kam G., Nijjer M., Stenner C. and Cheeptham N., 2020. Culture dependent analysis of bacterial diversity in Canada's Raspberry Rising Cave revealed antimicrobial properties. International Journal of Speleology, 49 (1), 43-53. Tampa, FL (USA) ISSN 0392-6672 https://doi.org/10.5038/1827-806X.49.1.2291

\section{INTRODUCTION}

Microbial communities are able to exist and thrive in a multitude of environments, including those that are harsher habitats such as caves that were previously thought to be completely devoid of life (Coughlan et al., 2015). Challenging characteristics of some cave habitats include the lack of light, low and limited amounts of organic nutrients, higher humidity and higher concentration of minerals that are normally natural DNA blocking agents. These demanding features contribute to distinctive cave environments (Cheeptham et al., 2013; Ghosh et al., 2016), and each cave has unique characteristics. Hence, cave microorganisms must adapt to possess some specialized metabolic pathways to enable them to survive and thrive within them (Ghosh et al., 2016). The broad diversity of microorganisms within caves encompass members among Proteobacteria, Firmicutes and Actinobacteria 
(Barton \& Jurado, 2007; Cheeptham et al., 2013; Ghosh et al., 2016, 2017; De Mandal et al., 2017). In particular, cave sediments house interesting microbial communities that include species of Streptomyces, Arthrobacter, Leifsonia, Rhodococcus, Bacillus, Paenosporosarcina, Paenibacillus, Pseudomonas, Williamsia, Leifsonia, Nocardia, Devosia (Ghosh et al., 2016; 2017), and interactions due to the unique conditions of the cave environment (Barron et al., 2010). These bacterial communities exist within caves are able to acquire their energy in a number of ways, that comprises breaking down complex aromatic compounds, fixing volatile organics as well as carbon dioxide and nitrogen from the atmosphere, and oxidizing reduced metals within rocks (Barton \& Jurado, 2007; Ghosh et al., 2016). Due to the fact that there is limited and chemically complex nutrients within a cave system, very few microbial species are able to uptake and perform catabolic reactions for growth (Barton \& Jurado, 2007). Thus, many microbial communities work in a mutualistic cooperative relationship to overcome this nutrient limitation (Barton \& Jurado, 2007). The unique cave environment that possesses a myriad of bacterial communities can be utilized for the potential discovery of new antibiotics (Ghosh et al., 2016; Gosse et al., 2019).

The need for discovery of new antibiotics is on the rise, since pathogens continuously becoming resistant to antibiotics, and those currently available either not having specific inhibitory activities or pose concerned side effects (Cheeptham et al., 2013; Ghosh et al., 2016). In terms of the cave microbiome, a number of studies have been explored for its diversity and has exhibited a wide range of antimicrobial properties (Cheeptham, et al., 2013; Ghosh et al., 2017; Gosse et al., 2019). For instance, in a recent study from Iron Curtain Cave, Canada, two bacterial isolates were identified ICC 1 and ICC4, that exhibited antagonistic properties against the multidrug resistant E. coli strains (Ghosh et al., 2017). Further genomic and metabolome analysis revealed that though the isolates are highly homologous with the terrestrial bacteria Streptomyces lavendulae but there were not the same, and possess expanded metabolic potentials (Gosse et al., 2019). These results have extended potential scopes from the caves and more extreme environments to be an effective resource for novel biologics and antibiotics (Ghosh et al., 2016).

In this study, we investigated the diversity of cultivated bacteria from seven different locations within the Raspberry Rising Cave, Canada, which has never been reported earlier. The phylogenetic analysis of $16 \mathrm{~S}$ rRNA gene sequences of the cultivable bacteria were performed and furthermore, antimicrobial properties of these cultivated bacteria against the multidrug resistant bacterial strains were assessed. The TupperRaspberry cave system has fairly demonstrated us that it could be a potential source for some crucial microbes, such as phyla belonging to Actinomycetes, Proteobacteria, Firmicutes, Bacteroidetes, and novel biomolecules.

\section{MATERIALS AND METHODS}

\section{Cave description: The Tupper-Raspberry cave system}

In Glacier National Park of Canada, a large sink takes meltwater from the Tupper Glacier. Known as Tupper Sink, water entering it was dye-traced by Ford and others from the Karst Research Group at McMaster University (Ford, 1967). The waters were positively traced to a spring $483 \mathrm{~m}$ lower and $1940 \mathrm{~m}$ distant. This spring, known as Cascade Cave, or Raspberry Rising, has been known for over a hundred years. This spring had been explored by cavers and open cave passages characterized by a flowing streamway were explored for $70 \mathrm{~m}$ to a sump. The sump was first passed by cave diving methods in 1972, where the passage rose from the water and emerged into an air-filled room with the water flow emanating from a high waterfall (Rollins, 2004). This waterfall obstacle remained unpassed until modern explorations began in 2012 (Graham \& Stenner, 2019).

The system is obstructed by water at both ends, by the sump $70 \mathrm{~m}$ after the entrance and by the sink at the top taking the meltwater from the Tupper Glacier. Exploration of the cave is limited to the winter months, due to dangerous flow rates which prevent diving through the sump and contribute to high water levels within the remainder of the cave. In between the sump and the Tupper Sink, an open, vadose cave system is present. Once past the waterfall, a mixture of open cave passages and large rooms have been explored, in a cave system with multiple levels. Five flooded sumps have been discovered and explored, so far, and the cave system has proven to be remarkable due to the quantity and quality of unique speleothems (Graham \& Stenner, 2019). The cave system is confined to a 20-60 m wide marble band sandwiched between calcareous slates and garnet schist identified this system as a classic Type 1 stripe-karst hydrology (Yonge, 2013).

The system has now been explored to 5,495 $\mathrm{m}$ in length and a vertical range of $219 \mathrm{~m}$. As of January 2019 , it is the longest marble cave system in Canada, the tenth longest and $26^{\text {th }}$ deepest overall cave in Canada and is the second longest cave in all of Canada's National Parks (Graham \& Stenner, 2019).

The system had only been explored to the waterfall immediately after the sump, resulting in $76 \mathrm{~m}$ of surveyed cave passage (Rollins, 2004). The remainder of the cave passages, having only been explored since 2012, had been devoid of human contact. The majority of passages, outside of the main route within the cave, were only visited during initial surveying and have not otherwise seen human traffic. This represents a unique opportunity for cave sediments and speleothem sample collections in a cave system while it underwent initial exploration.

The Tupper cave system is designated as an Environmentally-Sensitive Site within Parks Canada Zone 2 Wilderness. Entry into an EnvironmentallySensitive Site requires the highest level of care in order to protect sensitive geological resources and ensure minimal intervention in ecological processes. 
Exploration and research in Raspberry Rising were made possible by Parks Canada via "Tupper Cave System (Tupper Sink/Raspberry Rising) Exploration" Research and Collection Permit GLA-2016-23196.

\section{Sample sites and site selection}

Sample sites within the cave were chosen for their diversity and consisted of locations within the cave that had distinctly different features from one another. These sites were of varying distances from the entrance, cave sediment types, and speleothem types. Cave sediment samples were collected aseptically from seven different sampling areas from locations in the cave beyond the initial sump $70 \mathrm{~m}$ from the entrance (Fig. 1). The average cave sediment temperatures measured was $4.8^{\circ} \mathrm{C}$.

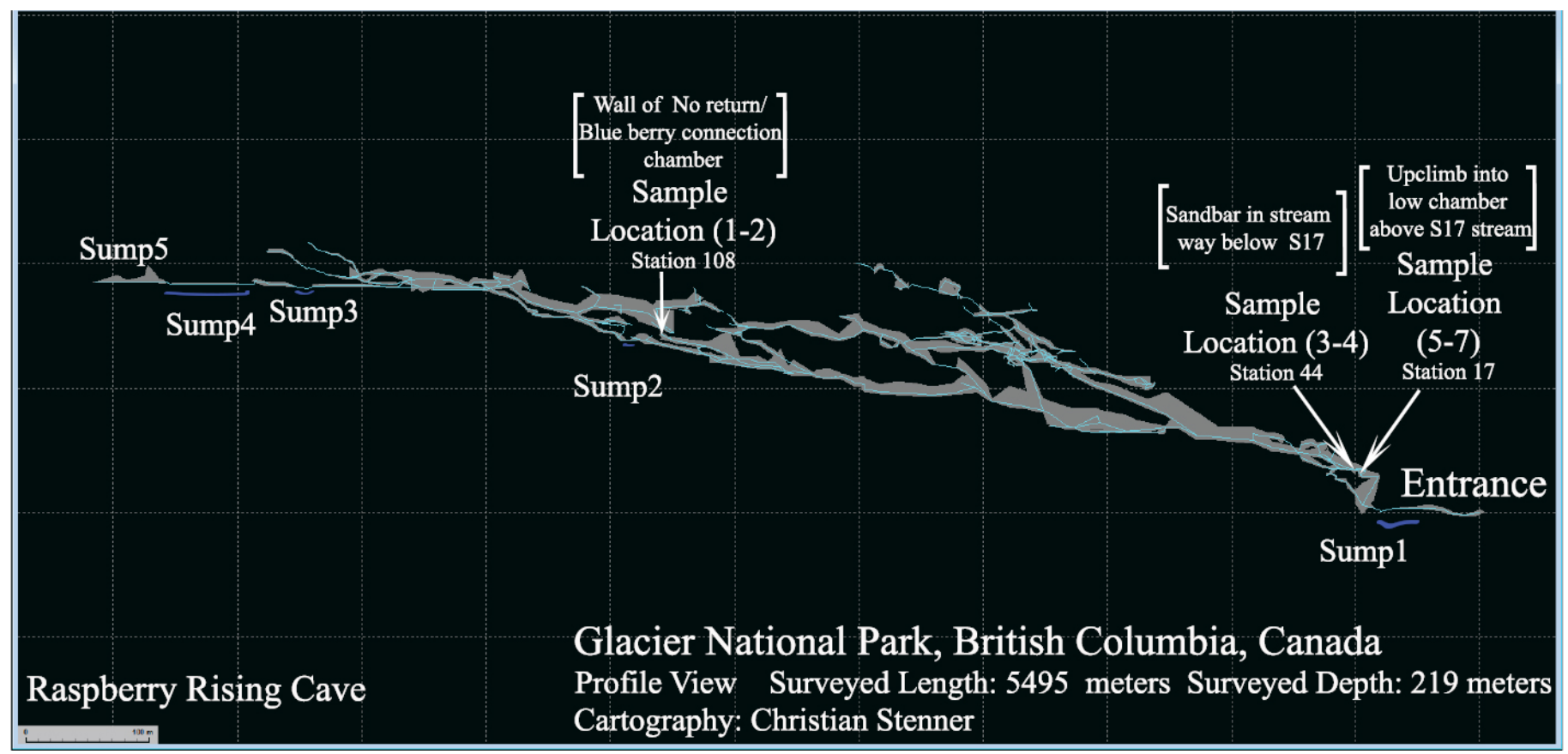

Fig. 1. Map of Raspberry Rising Cave in the Glacier National Park, BC. The map is represented from right to left as designated by cave 'Entrance', the starting point of the cave. The white arrow indicates the sample locations while the description in the square parenthesis specifies the location characteristics.

\section{Samples 1 and 2}

During the exploration of the cave on 9 April 2017, a squeeze between breakdown rocks revealed a small unexplored room connecting two known passages approximately $750 \mathrm{~m}$ from the entrance. This room was home to a sloping floor of loose sediment. With this opportunity to collect cave sediments which unequivocally had not been disturbed by humans at this time samples were collected of both top cave sediments and cave sediments from a dig of one-ft depth (Fig. 1) (Supplementary Table 1).

\section{Samples 3 and 4}

These samples of cave sediments were located in passage characterized by an active stream flow 123 $\mathrm{m}$ from the entrance. The cave sediments were in a sandbar like deposit to the side of the flowing water. This sandbar is expected to have increased water saturation or even could be submerged every summer due to increased flow rates from the meltwater of the Tupper Glacier entering the sink. Top cave sediments and cave sediments from $1 / 2 \mathrm{ft}$ deep were separately sampled, deeper cave sediments were unobtainable due to the dig hitting a layer of bedrock (Fig. 1) (Supplementary Table 1).

\section{Sample 5, 6, and 7}

Samples 5, 6, and 7 were all co-located in a rift passage, high on a ledge approximately 4 meters above the active stream way and $119 \mathrm{~m}$ from the entrance.
This area is expected to remain dry during summer floods. On the wall of the ledge a patch of multicolored loose flaky material approximately $50 \mathrm{~cm}$ by $30 \mathrm{~cm}$ was located. This material was scraped from the wall using sterile instruments and captured as Sample 5. Sample 7 was from the same patch of material on the wall but a specifically loose and powdery section that was all orange colored. Sample 6 consisted of scrapings, in the form of powder, from a vein of orange material on the ceiling close to the wall mat (Fig. 1) (Supplementary Table 1).

\section{Sample collection and bacterial isolation}

Approximately $10 \mathrm{~g}$ of cave sediment samples (Sample \#1-4) and cave wall scrapings (Sample \#5-7) (Fig. 2) were placed in sterile $250 \mathrm{~mL}$ volumetric flask. The samples were rinsed with sterile deionized water on a shaking incubator at $8^{\circ} \mathrm{C}, 150 \mathrm{rpm}$ overnight. One hundred microliter of the undiluted and decimally diluted $\left(10^{0}, 10^{-1}, 10^{-2}, 10^{-3}\right)$ cave sediment washings were plated on the three different media plates, namely R2A (Teknova, Hollister, CA, USA), HickeyTresner (HT) (Yeast extract $0.1 \%$, Beef extract $0.1 \%$, $\mathrm{N}-\mathrm{Z}$ Amine $0.2 \%$, Dextrin 1\%, pH 7.3) (Cheeptham et al., 2013) (Campbell Company, Toronto, ON, Canada), and Difco ${ }^{\mathrm{TM}}$ Actinomycetes Isolation (AI) Agar media (Thermo Fisher Scientific Inc., Waltham, MA, USA). The plates were incubated at $8^{\circ} \mathrm{C}$ till 7-8 weeks/until the visible colonies were observed. Morphologically distinguishable colonies were selected and re-streaked 

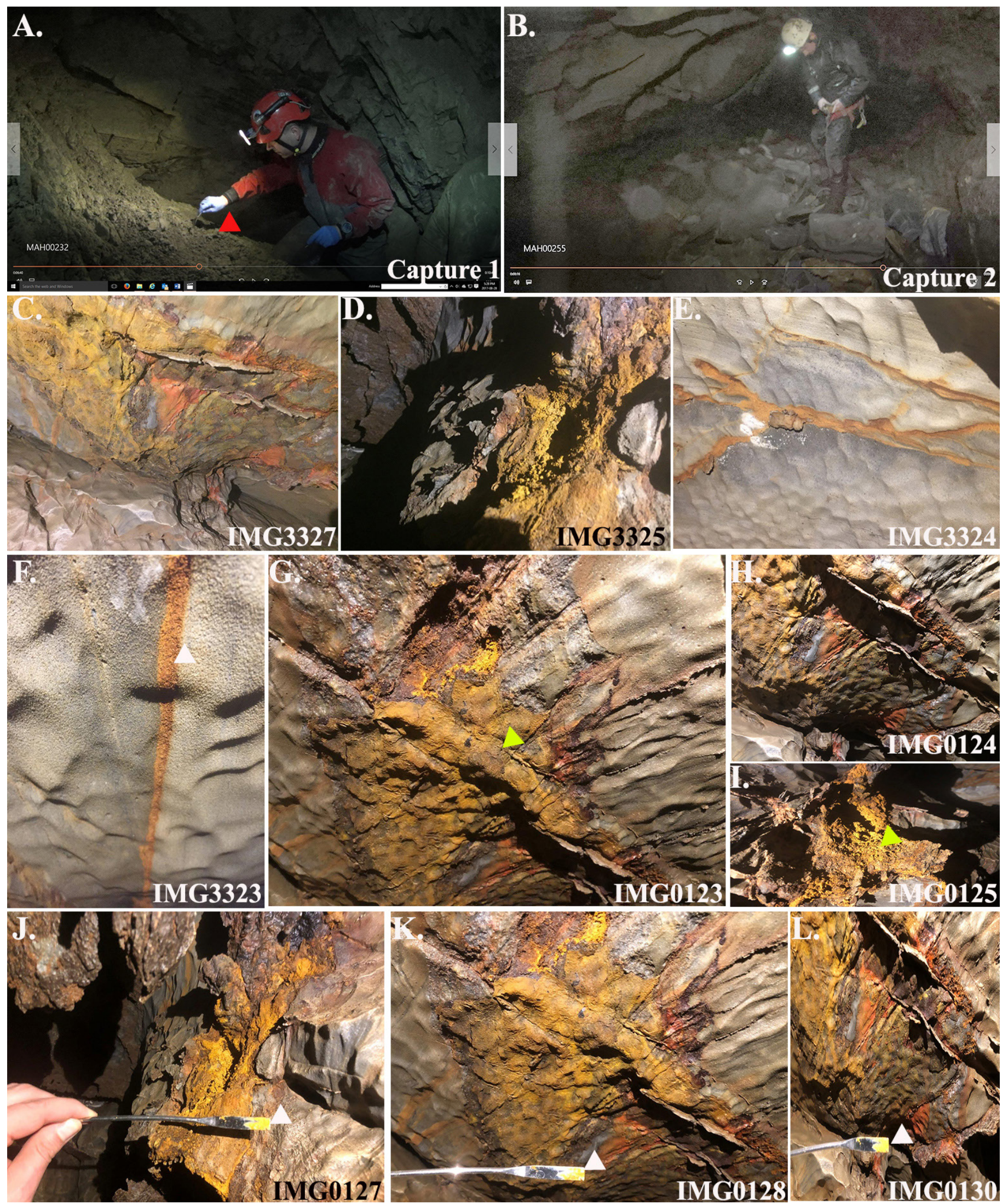

Fig. 2. Raspberry Rising Cave, Canada. A) Sampling site $\approx 750 \mathrm{~m}$ from the entrance; B) Sampling site $123 \mathrm{~m}$ from the entrance; C), D), E), F), G), $\mathrm{H}), \mathrm{I}), \mathrm{J}), \mathrm{K}$ ) and L) are the sampling sites $119 \mathrm{~m}$ from the entrance; The red, yellow and white arrow head indicates the cave sediments, yellow microbial mats and sampled cave wall scrapings respectively.

on the same media plates to obtain pure cultures. Each of the pure bacterial isolates were further inoculated in $3 \mathrm{~mL}$ volume of the respective broth media (R2A, HT, AI), incubated for a period of 1-2 weeks, followed by bacterial genomic DNA extraction. An aliquot of the grown cultures was stored in $20 \%(\mathrm{v} / \mathrm{v})$ glycerol at $-80^{\circ} \mathrm{C}$.

\section{MOLECULAR TAXONOMY}

\section{Genomic DNA extraction and sequencing}

Genomic DNA (gDNA) extraction from the bacterial isolates were performed as per previous studies (Hoffman \& Winston, 1987; Ghosh et al., 2017). Following the extraction, the gDNA was subjected to 
polymerized chain reaction amplification of the $16 \mathrm{~S}$ rRNA gene as described previously (Ghosh et al., 2017). The $27 \mathrm{~F}$ (5'-AGAGTTTGATCMTGGCTCAG-3') and 1492R (5'-TACGGYTACCTTGTTACGACTT-3') primers were used for the amplification reaction. The PCR amplicons obtained were further resolved on an Ethidium bromide -Agarose $(0.8 \%)$ gel in order to confirm their amplification. The unpurified amplicons were sent to Macrogen, Seoul, South Korea for nucleotide sequencing. The DNA sequences obtained were analyzed using the BLAST algorithm with the available sequences in the GenBank at the National Center for Biotechnology Information (NCBI) http://www.ncbi.nih.nlm.nih.gov/genebank/index.html (Altschul, et al., 1997). 16S rRNA gene sequences were identified with the $>98 \%$ identity and $>80 \%$ coverage to the closest homologue in the GenBank and DNA Data Bank of Japan and were assigned with gene accession numbers (Supplementary Table 3). The sequences that were not allotted with the GenBank or DDBJ number will be considered for further analysis.

\section{Molecular Phylogenetic analysis}

The evolutionary history was inferred using the Neighbor-Joining method (Saitou \& Nei, 1987). The optimal tree with the sum of branch length = 2.09133087 is shown. The percentage of replicate trees in which the associated taxa clustered together in the bootstrap test (1000 replicates) are shown next to the branches (Felsenstein, 1985). The tree is drawn to scale, with branch lengths in the same units as those of the evolutionary distances used to infer the phylogenetic tree. The evolutionary distances were computed using the Maximum Composite Likelihood method (Tamura et al., 2004) and are in the units of the number of base substitutions per site. The analysis involved 103 nucleotide sequences. Codon positions included were $1 \mathrm{st}+2 \mathrm{nd}+3 \mathrm{rd}+$ Noncoding. All positions containing gaps and missing data were eliminated. There was a total of 250 positions in the final dataset. Evolutionary analyses were conducted in MEGA6 (Tamura et al., 2013).

\section{Antimicrobial activity determination}

The cave bacterial isolates were subjected for antimicrobial activities screening against the multidrug resistant (MDR) and regular non-resistant bacterial strains. The MDR E. coli (New Delhi strain) \#15-318, E. coli \#15-102 and methicillin-resistant Staphylococcus aureus (MRSA)-43300 while the regular non-resistant strains E. coli-33 and S. aureus were chosen. All the test strains used were procured from our previous studies (Ghosh et al., 2017; Ghosh et al., 2018). The bacterial strains were inoculated in $3 \mathrm{~mL}$ of the nutrient broth (Criterion ${ }^{\mathrm{TM}}$ Dehydrated CultureMedia, Hardy Diagnostics, CA, USA) and incubated overnight on a shaking test tube rotator overnight at $37^{\circ} \mathrm{C}$. The antimicrobial activities assay was conducted employing seeded agar method. All the tested bacterial strains were inoculated at a concentration of $10^{6} \mathrm{cfu} / \mathrm{mL}$ in $250 \mathrm{~mL}$ molten agar media with a gentle shaking and poured in a Nunc ${ }^{\circledR}$ Bioassay Dish (245 mm x 245 mm x 25 mm)
(Cole-Parmer Scientific Experts, Montreal, QC, Canada). Two screening techniques, the plug and the tooth pick assays, were adopted to screen the cave bacterial isolates against the tested bacterial strains. The former technique involved aseptically cutting of the agar plugs ( 0.5 square centimeter) using sterile scalpel from each of the cave bacterial culture plate, while the latter include aseptically picking up of the cave bacterial colony using sterile tooth picks. Both agar plugs and the bacterial isolate were finally placed on to the tested microbe's-seeded agar plates. The antimicrobial assay plates were prepared in duplicates and incubated at $8^{\circ} \mathrm{C}$ for a period of $2-3$ days. The antimicrobial activities were determined as the zone of inhibition around each bacterial colony. The diameter of the zone of the inhibition was measured manually with electronic Vernier caliper (Guilin, Guangxi, China).

\section{RESULTS}

\section{Bacterial diversity}

A total of 103 bacteria, based on their colony characteristics on the specific culture growth media, were isolated from cave sediments and wall scrapping samples of the Raspberry Rising Cave. A set of 34 bacteria each were isolated on isolated on R2A- and HT- agar media while 35 bacteria were cultivated on AI-agar (Table 1).

Genomic DNA extraction were performed from each the cultivated bacterial isolates followed by the 16S rRNA gene amplification. The PCR amplification revealed that the amplicons ranging from 1300-1500 bp. Based on the nucleotide sequencing of each of the rDNA amplicons, the bacterial isolates were categorized into three major phyla of Proteobacteria, Actinobacteria and Bacteroidetes. Further investigations, revealed the genera of Pseudomonas (48.54\%) exhibited the majority of the population followed by Rhodococcus $(39.80 \%)$ and Flavobacterium (3.88\%). The genus Janthinobacterium and Arthrobacter contributed about $2.91 \%$ each, of the total population while, $0.99 \%$ bacterial population were recognized as endophytic Proteobacteria (Fig. 3) (Supplementary Table 2, Supplementary Table 3). Noteworthy, $5.82 \%$ of the bacterial population exhibited $\leq 98 \%$ when compared to the available 16 S rRNA gene sequences and could not be assigned with the Gene Accession numbers neither from the GenBank nor from the DNA Data Bank of Japan (DDBJ) (Supplementary Table 2, Supplementary Table 3).

The Pseudomonas and Rhodococcus were found to be widely distributed in all the sampling points that includes sampling points $1,2,3,4,5,7$ and 2,3,4,5,6,7 respectively while Flavobacterium and Janthinobacterium lividum were distributed at two and three sampling points respectively. Paeniglutamicibacter sp. and Arthrobacter sp. were scarcely distributed and only observed at a single sampling point (Fig. 3).

\section{Phylogenetic analysis}

Dendogram deduced from the 16S rRNA gene sequences of these bacteria revealed that Proteobacteria 
Table 1. Sampling locations with their respective characteristics in the Raspberry Rising Cave (RRC). Also, denoting the isolation media used to cultivate the bacterial isolates.

\begin{tabular}{|c|c|c|c|c|}
\hline Samples & Sampling locations & Location characteristics & $\begin{array}{c}\text { Isolation culture } \\
\text { media }\end{array}$ & Bacterial isolates \\
\hline \multirow{3}{*}{1} & \multirow{3}{*}{ Wall of No Return } & \multirow{3}{*}{ Cave sediments 1 FT depth } & $\mathrm{R} 2 \mathrm{~A}$ & RRC1-RRC5 \\
\hline & & & HT & RRC6-RRC7 \\
\hline & & & Act & RRC8-RRC14 \\
\hline \multirow{3}{*}{2} & \multirow{3}{*}{ Wall of No Return } & \multirow{3}{*}{ Top Cave sediments } & $\mathrm{R} 2 \mathrm{~A}$ & RRC15-RRC20 \\
\hline & & & HT & RRC21-RRC25 \\
\hline & & & Act & RRC26-RRC29 \\
\hline \multirow{3}{*}{3} & \multirow{3}{*}{ Station 44} & \multirow{3}{*}{ Top Cave sediments } & $\mathrm{R} 2 \mathrm{~A}$ & RRC30-RRC34 \\
\hline & & & HT & RRC35-RRC39 \\
\hline & & & Act & RRC40-RRC45 \\
\hline \multirow{3}{*}{4} & \multirow{3}{*}{ Station 44} & \multirow{3}{*}{ Cave sediments $1 / 2 \mathrm{FT}$ depth } & $\mathrm{R} 2 \mathrm{~A}$ & RRC46-RRC49 \\
\hline & & & $\mathrm{HT}$ & RRC50-RRC54 \\
\hline & & & Act & RRC55-RRC59 \\
\hline \multirow{3}{*}{5} & \multirow{3}{*}{ Station 17} & \multirow{3}{*}{ Wall Scraping } & $\mathrm{R} 2 \mathrm{~A}$ & RRC60-RRC65 \\
\hline & & & HT & RRC66-RRC71 \\
\hline & & & Act & RR72-RR76 \\
\hline \multirow{3}{*}{6} & \multirow{3}{*}{ Station 17} & \multirow{3}{*}{ Wall Scraping } & $\mathrm{R} 2 \mathrm{~A}$ & RRC77-RRC80 \\
\hline & & & HT & RRC81-RRC85 \\
\hline & & & Act & RRC86-RRC88 \\
\hline \multirow{3}{*}{7} & \multirow{3}{*}{ Station 17} & \multirow{3}{*}{ Wall Scraping } & $\mathrm{R} 2 \mathrm{~A}$ & RRC89-RRC92 \\
\hline & & & HT & RRC93-RRC98 \\
\hline & & & Act & RRC99-RRC103 \\
\hline
\end{tabular}

(51.45\%), were the major phylum followed by Actinobacteria (43.68\%) and Bacteroidetes (3.88\%). Remarkably, only the class Gammaproteobacteria was identified as the major class (94.44\%) among the Proteobacteria population followed by Betaproteobacteria (5.55\%) (Supplementary Table 3). Furthermore, the five antimicrobial bacterial isolates RRC48 (Pseudomonas sp.), RRC23 (Pseudomonas frederiksbergensis), RRC36 (Flavobacterium sp.), RRC38 (Rhodococcus sp.) and RRC75 (Rhodococcus sp.) were identified under the phylum Proteobacteria, Bacteroidetes and Actinobacteria, respectively (Fig.4).

\section{Antimicrobial activities of cave bacteria}

Five bacterial isolates were observed to exhibit antimicrobial activities. RRC23 (close homologue: Pseudomonas frederiksbergensis, 99.77\% identity) and RRC75 (close homologue: Rhodococcus sp., 99.85\% identity) showed antimicrobial activities against Escherichia coli \#15-318 while RRC48 (close homologue: Pseudomonas sp., 84.58\% identity) exhibit against Staphylococcus aureus (MRSA). RRC36 (close homologue: Flavobacterium sp., 99.70\% identity) and RRC38 (close homologue: Rhodococcus sp., 100\% identity) showed antimicrobial activities against the non-pathogenic Staphylococcus aureus strain (Table 2). Intriguingly, RRC48 showed a low identity $(84.58 \%)$ and query coverage $(68 \%)$ to its close homologue Pseudomonas sp. and therefore was not deposited to the Genbank or DDBJ.

All these bacteria that exhibited antimicrobial activities were isolated from sample location 2 (RRC23), sample location 3 (RRC36 and RRC38), sample location 4 (RRC48) and sample location 7 (RRC75). Notably, all these sampling sites, besides sample location 2 at the Station 108, were from Station 17 and Station 44, adjacent to the cave entrance (Fig. 1) (Table 1).

\section{DISCUSSION}

Raspberry Rising Cave is karstic cave, located in the Glacier National Park's Tupper mountain system in British Columbia, Canada. Seven locations in the cave were identified from where cave sediments/wall scrapings were sampled. The samples were processed and a cultivation-/PCR-based study were carried out for the first time to elucidate the bacterial diversity of this cave that revealed 103 bacterial isolates. Notably, the samples were incubated at $8^{\circ} \mathrm{C}$, although, the temperature of the cave was measured as $4.8^{\circ} \mathrm{C}$. A higher incubation temperature was employed as cave bacteria can exhibit confluent growth at temperatures in the range of $5-45^{\circ} \mathrm{C}$ (Laiz Trobajo et al., 2003).

The cave typically showed the presence of yellow mat/microbial communities (Fig. 2), commonly observed both in karstic and lava caves (Porca et al., 2012; Velikonja et al., 2014; Riquelme et al., 2015). Our study, though preliminary, has identified different bacterial strains with Proteobacteria as the major phylum followed by Actinobacteria and Bacteroidetes. These findings were in consistent to a few previous cultivation-based studies on bacterial phylogenetic diversity of the karstic caves where Proteobacteria was recognized as a predominant bacterial population (Barton et al., 2004; Lu et al., 


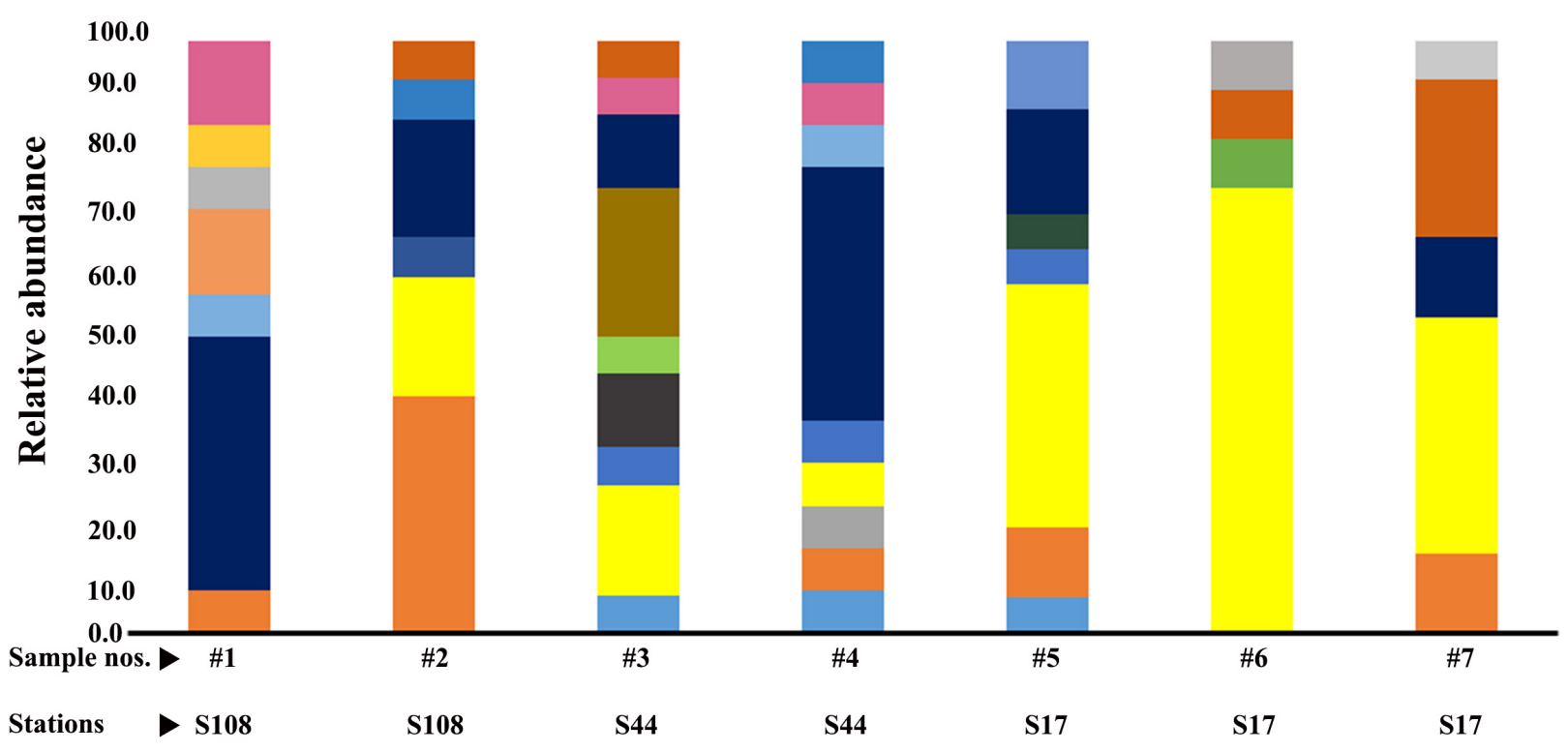

Sampling locations in the Raspberry Rising Cave

Flavobacterium sp.

Rhodococcus qingshengii

Pseudomonas vancouverensis

Janthinobacterium lividum

Arthrobacter sp.

Arthrobacter oryzae
Pseudomonas fredriksbergensis

Paeniglutamicibacter sp.

Pseudomonas migulae

Pseudomonas koreensis

Pseudomonas mandelii

Rhodococcus boritolerans
Pseudomonas fluorescens

Pseudomonas thivarvalensis

Nocardia coeliaca

Endophytic bacterium

Flavobacterium olei
Rhodococcus sp.

Pseudomonas grimontii

Pseudomonas sp.

Pseudomonas aveilannae

Rhodococcus erythropolis

Fig. 3. Taxonomical distribution of bacterial isolates from the Raspberry Rising Cave. The vertical rectangular stalked columns indicate the relative abundance of the bacterial population from each of the samples.

2018; Yasir, 2018). Proteobacteria phylum was dominated by the class Gammaproteobacteria with Pseudomonas sp. observed as the major genera in accordance to previous studies (Barton et al., 2004; Banerjee \& Joshi, 2016; Yasir, 2018). Proteobacterial population seldom observed to be the dominant class in most of the cave bacterial diversity studies with the majority of the bacterial population has been shown as Actinobacteria (Axenov-Gribanov et al., 2016; Ghosh et al., 2016, 2017; Lavoie et al., 2017). However, a few studies have reported Proteobacteria as the most abundant phylum (Sauro et al., 2018; Yasir, 2018; Barron et al., 2010). Our study has revealed $94.44 \%$ of the proteobacterial community was represented by the class Gammaproteobacteria. These findings were consistent with the previous cultivation-based studies where class Gammaproteobacteria were shown to constitute the major bacterial population (Banerjee \& Joshi, 2016; Yasir, 2018). For instance, bacterial diversity study on the Meghalayan caves in NorthEast India, exposed thirty-two different cultivable bacterial species belonging to sixteen different genera where majority belongs to Pseudomonas and Bacillus (Banerjee \& Joshi, 2016). Furthermore, we have reported Betaproteobacteria as the less abundant class representing Janthinobacterium sp. (2.91\% of the total population) as the only genus (Fig. 4). These observations were in line with previous studies where paired end Illumina was conducted on the bacterial diversity using the V3 region of the 16S DNA from five unknown and unexplored caves of Mizoram, the Northeast India, showing Alpha- and Gammaproteobacteria, the dominant phylotypes while Betaproteobacteria constitute the minor population (De Mandal et al., 2017). Likewise, another study conducted on the microbial diversity and functionality on silica mobility in orthoquartzite caves also reported Janthinobacterium as the less abundant genus among the betaproteobacterial population (Sauro et al., 2018). Our study has reflected a previous literature that has shown Rhodococcus to be the abundant genera among the Actinobacteria (De Mandal et al., 2015), although, in most of the cases Rhodococcus is a rare Actinobacteria (Groth et al., 1999, Adam et al., 2018). Phylum Bacteroidetes with the genus Flavobacterium has been identified as the minor population in our study as stated in the previous findings (Rusznyak et al., 2012; Carmichael et al., 2013).

Five bacterial isolates (RRC23, RRC36, RRC38, RRC48, RRC75) exhibited antagonistic activities against the multidrug resistant strains of $E$. coli and Staphylococcus aureus revealed in our study. Most of 


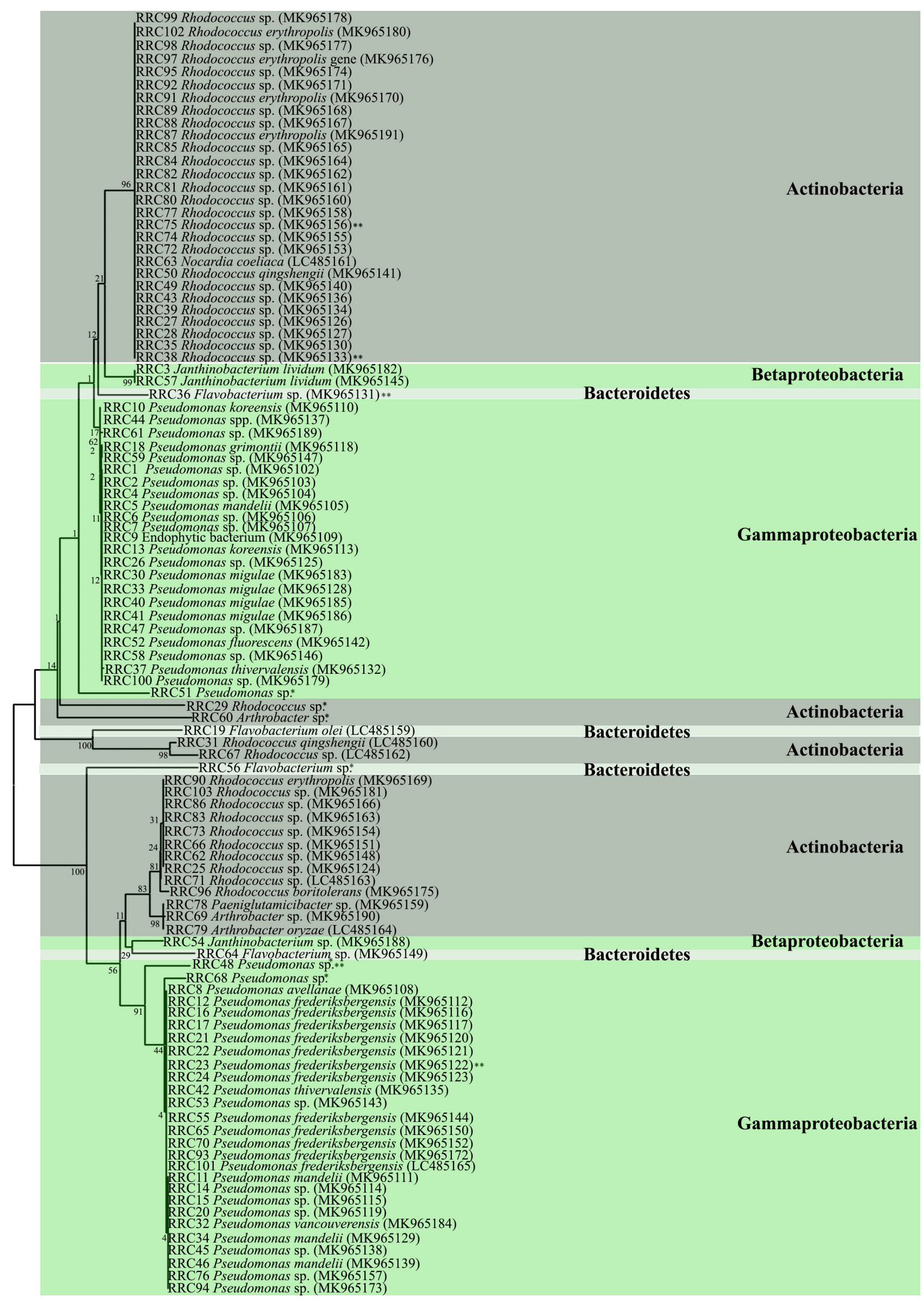

$\longdiv { 0 . 0 5 }$

Fig. 4. Maximum Likelihood tree showing the phylogenetic position of the Raspberry Rising Cave bacterial isolates. The $16 \mathrm{~S}$ ribosomal operons were obtained from the NCBI database, aligned by MUSCLE with default parameters and the phylogenetic dendrogram was constructed using MEGA6 by neighbor-joining method. Bootstrap confidence levels of 1000 re-samplings were indicated at the nodes. The alphanumeric characters in the parenthesis specifies the gene accession numbers. The isolates marked with a single asterisk indicate lower homology towards their closest relatives (accession numbers were not assigned) while the double asterisks exhibit the isolates with antimicrobial properties. RRC is the abbreviation used for Raspberry Rising Cave. 
Table 2. Antimicrobial activity screening of the RRC isolates against the MDR and normal bacterial strains. ' + ' and '-' denotes 'antimicrobial' activities and 'no antimicrobial' activities respectively.

\begin{tabular}{|c|c|c|c|c|c|c|c|}
\hline \multirow{2}{*}{$\begin{array}{c}\text { Bacterial } \\
\text { isolates }\end{array}$} & \multirow{2}{*}{$\begin{array}{c}\text { Growth } \\
\text { media }\end{array}$} & $\begin{array}{c}\text { Sample locations/ } \\
\text { location description/ } \\
\text { sample type }\end{array}$ & \multicolumn{5}{|c|}{ Test microorganisms } \\
\cline { 3 - 7 } RRC23 & HT & $\begin{array}{c}\text { Station 108/Wall of no } \\
\text { return/cave sediments }\end{array}$ & - & - & + & - & E. coli \\
RRC36 & HT & $\begin{array}{c}\text { Station 44/ Sandbar in } \\
\text { streamway below S. 17/ } \\
\text { cave sediments }\end{array}$ & - & - & - & + \\
\hline RRC38 & HT & $\begin{array}{c}\text { Station 44/ Sandbar in } \\
\text { stream way below S. 17/ } \\
\text { cave sediments }\end{array}$ & - & - & - & S. aureus & MRSA-43300 \\
\hline RRC48 & R2A & $\begin{array}{c}\text { Station 44/ Sandbar in } \\
\text { stream way below S. 17/ } \\
\text { cave sediments }\end{array}$ & - & - & - & - \\
\hline RRC75 & $\begin{array}{c}\text { Actinomyces } \\
\text { media }\end{array}$ & $\begin{array}{c}\text { Station17/ Up climb into } \\
\text { low chamber above S.17 } \\
\text { stream/wall scrapings }\end{array}$ & - & - & - & - \\
\hline
\end{tabular}

these isolates belonged to the phylum Actinobacteria and Proteobacteria. RRC38 and RRC75 were both identified as the closest homologues to Actinobacteria (Genus: Rhodococcus sp.) while RRC 23 and RRC 48 as Gammaproteobacteria (Genus: Pseudomonas). Earlier studies have shown that Actinobacteria to be a promising resource for the bioactive compounds (Ghosh et al., 2016, 2017; Rangseekaew \& PathomAree, 2019). The genera Streptomyces predominantly exhibited antagonistic effect against bacteria and fungi (Ghosh et al., 2017, Rangseekaew \& PathomAree, 2019). For instance, a study on an Italian cave, Grotta dei Cervi, have shown bioactive compounds Cervimycin A, B, C, and D, extracted from Streptomyces tendae strain HKI 0179, exhibited antagonistic effect against Gram-positive bacteria ( $B$. subtilis and $S$. aureus) as well as multidrug resistant S. aureus (MRSA), vancomycin-resistant Enterococcus faecalis (VRE) and efflux-resistant S. aureus EfS4 (Herold et al., 2005). However, the genera Rhodococcus were not reported expansively from the cave habitat to possess antimicrobial activities. An earlier study has demonstrated isolation of Rhodococcus sp. from the limestone deposit sites in Hundung, Manipur, India, that only showed biocontrol activity against the rice fungal pathogen (Nimaichand et al., 2015). Pseudomonas sp. was rarely identified to exhibit antimicrobial activities from the cave environment. For instance, a previous study has reported Pseudomonas fluorescens, isolated from the Magura Cave, Bulgaria, has exhibited antimicrobial effect against $P$. aeruginosa and Rhodutorula mucilaginosa displaying $20 \mathrm{~mm}$ and $16 \mathrm{~mm}$ as the zone of inhibition respectively (Tomova et al., 2013; Ghosh et al., 2016). Our study has identified RRC 36 (close homologue: Flavobacterium sp.) to exhibit antibacterial activities against $S$. aureus. There is no study accounted until date for the antibacterial activities of Flavobacterium from the cave environment. However, a cultivation-based study from the Antarctic environments has reported antimycobacterial activities of Flavobacterium against Mycobacterium smegmatis and $M$. tuberculosis (Mojib, et al., 2010). Notably, it has also been observed that all the five isolates exhibited antimicrobial activities were retrieved from all the three stations of the cave $(17,44$, and 108) implying that the antimicrobial properties were relatively wide spread in terms of sampling areas and characteristics of the cave sediments within the cave. In addition, the antimicrobial activities were observed at $8^{\circ} \mathrm{C}$. However, a previous study has shown Antarctic bacteria produce antimicrobials at low temperature during their growth cycle for their competitive survival (O’Brien et al., 2004).

Taken together, our study has expanded a new understanding to the Canada's underground. To the best of our knowledge, this is the first attempt that intend to provide the in situ cultured bacterial diversity and antimicrobial activities from the Raspberry Rising Cave. Moreover, the antimicrobial activities exhibited by lesser studied genera such as Rhodococcus, Pseudomonas and Flavobacterium rather than the commonly studied Streptomyces has further opened new frontiers in antimicrobial research studies. Further investigations should emphasize to reveal the whole genome sequences, functional genomics, biochemical assays, fermentation structure elucidation, active component extraction and mode of action of these bacterial isolates in order to understand the underpinning mechanisms of their antimicrobial activities. However, our study gave a smaller snapshot of this cave habitat. Therefore, future study should focus on the metagenomic approaches to have holistic taxonomical and functional profiles of Raspberry Rising Cave microbiomes, in a way to bio-prospect antimicrobial genes/molecules of biotechnological and pharmaceutical relevance and further to elucidate the molecular mechanisms related to microbe-mineral interactions in cave.

\section{ACKNOWLEDGEMENTS}

Charlene Barker for assisting with sample collections and Kathleen Graham for coordinating exploration of the cave and permit with Parks Canada. Parks Canada for allowing the exploration and research in Raspberry Rising via "Tupper Cave System (Tupper Sink/Raspberry Rising) Exploration" Research and Collection Permit GLA-2016-23196. Comments from two anonymous reviews improved the content of this paper. 


\section{REFERENCES}

Adam D., Maciejewska M., Naome A., Martinet L., Coppieters W., Karim L., Baurain D. \& Rigali S., 2018 - Isolation, characterization, and antibacterial activity of hard-to-culture actinobacteria from cave moonmilk deposits. Antibiotics, 7: 28. https://doi.org/10.3390/antibiotics7020028

Altschul S.F., Madden T.L., Schaffer A.A., Zhang J., Zhang Z., Miller W. \& Lipman D.J., 1997 - Gapped BLAST and PSI-BLAST: a new generation of protein dataase search programs. Nucleic Acids Reseasrch, 25: 3389-3402. https://doi.org/10.1093/nar/25.17.3389

Axenov-Gribanov D.V., Voytsekhovskaya I.V., Tokovenko B.T., Protasov E.S., Gamaiunov S.V., Rebets Y.V., Luzhetskyy A.N. \& Timofeyev M.A., 2016 Actinobacteria isolated from an underground lake and moonmilk speleothem from the biggest conglomeratic karstic cave in Siberia as sourcs of novel biologically active compounds. PLoS One, 11: e0149216. https://doi.org/10.1371/journal.pone.0152957

Banerjee S. \& Joshi S., 2016 - Culturable bacteria associated with the Caves of Meghalaya in India contribute to speleogenesis. Journal of Cave and Karst Studies, 78: 144-157.

https://doi.org/10.4311/2015MB0131

Barron S.K., Murdock C.A., Blair B.G., Meade M.E. \& Barger T.W., 2010 - Analysis of bacterial diversity in soils from blowing spring cave (Lauderdale county, $A L)$. The Journal of the Alabama Acadamy of Science, 81: 1-10.

Barton H.A. \& Jurado V., 2007 - What's up down there? Microbial diversity in caves. Microbe, 2: 132-138.

Barton H.A., Taylor M.R. \& Norman P., 2004 - Molecular Phylogenetic analysis of a bacterial community in an oligotrophic cave environment. Geomicrobiology Journal, 21: 11-20.

https://doi.org/10.1080/01490450490253428

Carmichael M.J., Carmichael S.K., Santelli C.M., Strom A. \& Brauer S.L., 2013 - Mn(II)-oxidizing bacteria are abundant and environmentally relevant members of Ferromanganese deposits in caves of the Upper Tennessee River Basin. Geomicrobiology Journal, 30: $779-800$.

https://doi.org/10.1080/01490451.2013.769651

Cheeptham N., Sadoway T., Rule D., Watson K., Moote P., Soliman L.C., Azad N., Donkor K.K. \& Horne D., 2013 - Cure from the cave: volcanic cave actinomycetes and their potential in drug discovery. International Journal of Speleology, 42: 35-47.

https://doi.org/10.5038/1827-806X.42.1.5

Coughlan L.M., Cotter P.D., Hill C. \& Alvarez-Ordonez A., 2015 - Biotechnological applications of functional metagenomics in the food and pharmaceutical industries. Frontiers in Microbiology, 6: 672. https://doi.org/10.3389/fmicb.2015.00672

De Mandal S., Chatterjee R. \& Kumar N.S., 2017. Dominant bacterial phyla in caves and their predicted functional roles in $C$ and $N$ cycle. BMC Microbiology, 17: 90. https://doi.org/10.1186/s12866-017-1002-x

De Mandal S., Sanga Z. \& Kumar N.S., 2015-Metagenome sequencing reveals Rhodococcus dominance in Farpuk Cave, Mizoram, India, an Eastern Himalayan biodiversity hot spot region. Genome Announcements, 3: 1-2. https://doi.org/10.1128/genomeA.00610-15

Felsenstein J., 1985 - Confidence limits on phylogenies: An approach using the bootstrap. Evolution, 39: 783-791. https://doi.org/10.1111/j.1558-5646.1985.tb00420.x
Ford D.C., 1967 - Sinking creeks of Mount Tupper: A remarkable groundwater system in Glacier National Park. Canadian Geograhy, 11: 49-52. https://doi.org/10.1111/j.1541-0064.1967.tb00139.x

Ghosh S., Kuisiene N. \& Cheeptham N., 2016 - The cave microbiome as a source for drug discovery: Reality or pipe dream? Biochemical Pharmacology, 134: 18-34. https://doi.org/10.1016/j.bcp.2016.11.018

Ghosh S., Paine E., Wall R., Kam G., Lauriente T., Sangarmangkang P.C., Horne D. \& Cheeptham N., 2017 - In situ cultured bacterial diversity from Iron Curtain Cave, Chilliwack, British Columbia, Canada. Diversity, 9: 36. https://doi.org/10.3390/d9030036

Ghosh S., Persad E., Shiue T.Y., Lam C., Islam A., Mascibroda L.G., Sherman M.B., Smith T. \& Cheeptham N., 2018 - Explorative study on isolation and characterization of a microviridae G4 bacteriophage, EMCL318, against multi-drug-resistant Escherichia coli 15-318 - Antibiotics, 7: 92. https://doi.org/10.3390/antibiotics7040092

Gosse J.T., Ghosh S., Sproule A., Overy D., Cheeptham N. \& Boddy C.N., 2019 - Whole genome sequencing and metabolomic study of cave streptomyces isolates ICC1 and ICC4 - Frontiers in Microbiology, 10: 1020.

https://doi.org/10.3389/fmicb.2019.01020

Graham K. \& Stenner C., 2019 - The Tupper Cave System exploration, 2016-2018 - Report to Parks Canada. Calgary.

Groth I., Vettermann R., Schuetze B., Schumann P. \& Saiz-Jimenez C., 1999 - Actinomycetes in karstic caves of northern Spain (Altamira and Tito Bustillo). Journal of Microbiological Methods, 36: 115-122. https://doi.org/10.1016/S0167-7012(99)00016-0

Herold K., Gollmick F.A., Groth I., Roth M., Menzel K.D., Mollmann U., Grafe U. \& Hertweck C., 2005. Cervimycin A-D: a polyketide glycoside complex from a cave bacterium can defeat vancomycin resistance. Chemistry, 11: 5523-5530.

https://doi.org/10.1002/chem.200500320

Hoffman C.S. \& Winston F., 1987 - A ten-minute DNA preparation from yeast efficiently releases autonomous plasmids for transformation of Escherichia coli. Gene, 57: $267-272$.

https://doi.org/10.1016/0378-1119(87)90131-4

Laiz Trobajo L., Gonzalez G.M., Miguel J. \& Saiz-Jimenez C., 2003 - Microbial communities in caves: ecology, physiology, and effects on paleolythic paintings. In: Koestler R.J., V.H. Koestler A.E. Charola \& E.N.F. Fernando (Eds.), Art, biology and conservation: Biodeterioration of works of art. Metropolitan Museum of Art Yale University, New York, p. 210-225.

Lavoie K.H., Winter A.S., Read K.J., Hughes E.M., Spilde M.N. \& Northup D.E., 2017 - Comparison of bacterial communities from lava cave microbial mats to overlying surface soils from Lava Beds National Monument, USA. PLoS One, 12: e0169339.

https://doi.org/10.1371/journal.pone.0169339

Lu X.F., He Q.F., Wang F.K., Zhao R.Y. \& Zhang H., 2018 - Impact of tourism on bacterial communities of karst underground river: A case study from two caves in Fengdu, Chongqing. Journal of Environmental Sciences, 39: 2389-2399.

https://doi.org/10.13227/j.hjkx.201709005

Mojib N., Philpott R., Huang J.P., Niederweis M. \& Bej A.K., 2010 - Antimycobacterial activity in vitro of pigments isolated from Antarctic bacteria. Antonie van Leeuwenhoek, 98: 531-540. https://doi.org/10.1007/s10482-010-9470-0 
Nimaichand S., Devi A.M., Tamreihao K., Ningthoujam D.S. \& Li W.J., 2015 - Actinobacterial diversity in limestone deposit sites in Hundung, Manipur (India) and their antimicrobial activities. Frontiers in Microbiology, 6: 413. https://doi.org/10.3389/fmicb.2015.00413

O’Brien A., Sharp R., Russell N.J. \& Roller S., 2004 - Antarctic bacteria inhibit growth of foodborne microorganisms at low temperatures. FEMS Microbiology Ecology, 48: 157-167. https://doi.org/10.1016/j.femsec.2004.01.001

Porca E., Jurado V., Zgur-Bertok D., Saiz-Jimenez C. \& Pasic L., 2012 - Comparative analysis of yellow microbial communities growing on the walls of geographically distinct caves indicates a common core of microorganisms involved in their formation. FEMS Microbioogyl Ecology, 8: 255-266. https://doi.org/10.1111/j.1574-6941.2012.01383.x

Rangseekaew P. \& Pathom-Aree W., 2019 - Cave actinobacteria as producers of bioactive metabolites. Frontiers in Microbiology, 10: 387. https://doi.org/10.3389/fmicb.2019.00387

Riquelme C., Marshall Hathaway J.J., Enes Dapkevicius Mde L., Miller A.Z., Kooser A., Northup D.E., Jurado V., Fernandez O., Saiz-Jimenez C. \& Cheeptham N., 2015 - Actinobacterial diversity in volcanic caves and associated geomicrobiological interactions. Frontiers in Microbiology, 6: 1342.

https://doi.org/10.3389/fmicb.2015.01342

Rollins J., 2004 - Caves of the Canadian Rockies and Columbia Mountains. Rocky Mountain Books, 336 p.

Rusznyak A., Akob D.M., Nietzsche S., Eusterhues K., Totsche K.U., Neu T.R., Frosch T., Popp J., Keiner R., Geletneky J., Katzschmann L., Schulze E.D. \& Kusel K., 2012 - Calcite biomineralization by bacterial isolates from the recently discovered pristine Karstic Herrenberg cave. Applied Environmental Microbiology, 78: 11571167. https://doi.org/10.1128/AEM.06568-11

Saitou N. \& Nei M., 1987 - The neighbor-joining method: a new method for reconstructing phylogenetic trees.
Molecular Biology and Evolution, 4: 406-425.

https://doi.org/10.1093/oxfordjournals.molbev.a040454

Sauro F., Cappelletti M., Ghezzi D., Columbu A., Hong P.Y., Zowawi H.M., Carbone C., Piccini L., Vergara F., Zannoni D. \& De Waele J., 2018 - Microbial diversity and biosignatures of amorphous silica deposits in orthoquartzite caves. Scientific Reports, 8: 17569. https://doi.org/10.1038/s41598-018-35532-y

Tamura K., Nei M. \& Kumar S., 2004 - Prospects for inferring very large phylogenies by using the neighborjoining method. Proceedings of National Academy of Sciences USA, 101: 11030-11035.

https://doi.org/10.1073/pnas.0404206101

Tamura K., Stecher G., Peterson D., Filipski A. \& Kumar S., 2013 - MEGA6 - Molecular Evolutionary Genetics Analysis version 6.0-Molecular Biology and Evolution, 30: 2725-2729.

https://doi.org/10.1093/molbev/mst197

Tomova I., Lazarkevich I., Tomova A., Kambourova M. \& Vasileva-Tonkova E., 2013 - Diversity and biosynthetic potential of culturable aerobic heterotrophic bacteria isolated from Magura Cave, Bulgaria. International Journal of Speleology, 42: 65-67. https://doi.org/10.5038/1827-806X.42.1.8

Velikonja B.H., Tkavc R. \& Pašić L., 2014 - Diversity of cultivable bacteria involved in the formation of macroscopic microbial colonies (Cave Silver) on the walls of a cave in Slovenia. International Journal of Speleology, 43: 45-56.

https://doi.org/10.5038/1827-806X.43.1.5

Yasir M., 2018 - Analysis of bacterial communities and characterization of antimicrobial strains from cave microbiota. Brazilian Journal of Microbiology, 49: 248257. https://doi.org/10.1016/j.bjm.2017.08.005

Yonge C.J., 2013 - The Tupper Glacier Sink - Raspberry Rising Cave System, Glacier National Park, Canada: A remarkable example in stripe karst. Proceedings of the $16^{\text {th }}$ International Congress of Speleology, Brno, Czech Republic, p. 158-163. 